\title{
Surface- and volume-based investigation on influences of different Varestraint testing parameters and chemical compositions on solidification cracking in LTT filler metals
}

\author{
Maximilian Thomas ${ }^{1} \cdot$ Florian Vollert $^{2} \cdot$ Jens Weidemann ${ }^{1} \cdot$ Jens Gibmeier $^{2} \cdot$ Arne Kromm $^{1} \cdot$ Thomas Kannengießer $^{1}$
}

Received: 17 October 2019 / Accepted: 16 March 2020 / Published online: 27 March 2020

(C) The Author(s) 2020

\begin{abstract}
The subject of this study is how, and to what extent, Varestraint/Transvarestraint test results are influenced by both testing parameters and characteristics of evaluation methods. Several different high-alloyed martensitic LTT (low transformation temperature) filler materials, $\mathrm{CrNi}$ and $\mathrm{CrMn}$ type, were selected for examination due to their rather distinctive solidification cracking behaviour, which aroused interest after previous studies. First, the effects of different process parameter sets on the solidification cracking response were measured using standard approaches. Subsequently, microfocus X-ray computer tomography $(\mu \mathrm{CT})$ scans were performed on the specimens. The results consistently show sub-surface cracking to significant yet varying extents. Different primary solidification types were found using wavelength dispersive X-ray (WDX) analysis conducted on filler metals with varying $\mathrm{Cr} / \mathrm{Ni}$ equivalent ratios. This aspect is regarded as the main difference between the $\mathrm{CrNi}$ and CrMn-type materials in matters of cracking characteristics. Results show that when it comes to testing of modern highperformance alloys, one set of standard Varestraint testing parameters might not be equally suitable for all materials. Also, to properly accommodate different solidification types, sub-surface cracking has to be taken into account.
\end{abstract}

Keywords Solidification cracking · Varestraint testing $\cdot$ LTT filler metal $\cdot$ Microfocus X-ray computer tomography $(\mu C T)$

\section{LTT filler metals}

The use of low transformation temperature filler metals is an innovative way to reduce tensile residual stresses that commonly occur when welding high-strength steels. Through addition of alloying elements, like nickel and manganese, the martensite start $\left(\mathrm{M}_{\mathrm{S}}\right)$ temperature of these materials is considerably lower than for conventional filler metals. The increase in volume caused by the phase transition from austenite to martensite is hindered by the cold base material surrounding the weld, which leads to compressive stresses. This is

Recommended for publication by Commission II - Arc Welding and Filler Metals

Maximilian Thomas

maximilian.thomas@bam.de

1 Bundesanstalt für Materialforschung und -prüfung (BAM), Unter den Eichen 87, 12205 Berlin, Germany

2 Institute for Applied Materials IAM-WK, Karlsruhe Institute of Technology, Engelbert-Arnold-Straße 4, 76131 Karlsruhe, Germany counteracting the shrinkage-induced tensile stresses. The lower the $\mathrm{M}_{\mathrm{s}}$, the more pronounced this effect becomes. Tensile residual stresses can be reduced or even turned into compressive stresses.

The subject of low transformation temperature (LTT) has been intensively studied $[1,2]$. In particular, the proof that compressive residual stresses are formed [3, 4], the investigation of the mechanisms of stress formation [5, 6], and the effect on the fatigue strength $[7,8]$ have been the subject of many research projects. Recent publications also deal with extended topics such as microstructure and the associated mechanical properties [9-13], the behaviour during multilayer welding [14-18], and the application of LTT in beam welding [19].

However, the chemical composition of the most commonly used LTT approach, with $\mathrm{Cr}$ and $\mathrm{Ni}$ as the main alloying elements, still involves the risk of solidification cracking. Only a few investigations are addressing this topic [20-22]. These show that the tendency for cracking is very sensitive to the chemical composition. Above all, the carbon and nickel contents determine the extent of crack formation. 
The influence of the chemical composition of different LTT fillers on the tendency to solidification cracking is one of the main objectives of the present study. The different filler materials used in this regard stem from previous investigations aiming to evaluate the influence of the chemical composition on the $\mathrm{M}_{\mathrm{s}}$ temperature [21]. Their compositions are listed in Table 2 and shall be discussed in more detail later on.

As an example of the three alloy types examined in [21], Figs. 1, 2, and 3 show the cross sections produced by optical microscopy for multilayer welds. Lichtenegger and Bloech I etchant was chosen to contrast the weld microstructures. This etchant is well suited to reveal segregation in high-alloy welds. During manufacturing of the multilayer welds microcracks already appeared in individual cases (Figs. 1 and 3).

Alloys A and B, shown in Figs. 1 and 2, respectively, are both $\mathrm{Cr}$ and Ni based; their weld microstructures show similar characteristics. The structure is martensitic, which is etched blue and brown, and the micrographs give no indication of retained austenite. The prior austenite grain boundaries are partially visible. Some precipitations are present, independent of the varying carbon contents of the alloys. In the top layer of alloy A, a microcrack appeared along the boundary of two former austenitic cells. This location indicates a solidification crack. No further cracks were found in the cross sections.

Alloy $\mathrm{G}$ is $\mathrm{Cr}$ and $\mathrm{Mn}$ based, following a different LTT approach. Its weld microstructure is martensitic, which is etched brown as indicated in Fig. 3. Microsegregation is indicated by light and dark etched areas. Their appearance suggests a cellular structure, which is typical for primary austenitic solidifying welds. A microcrack was found in the weld root.

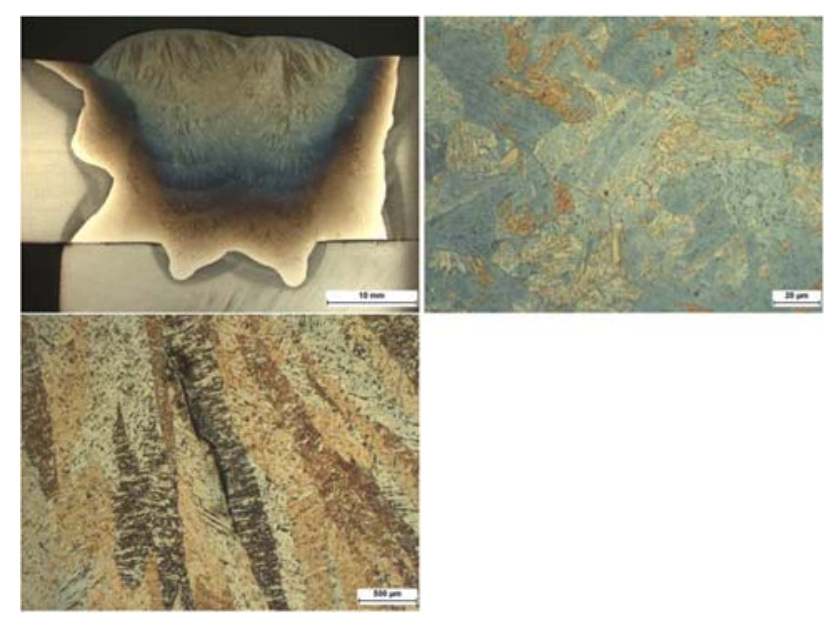

Fig. 1 Weld cross section and microstructure of LTT alloy A (microcrack in bottom left figure) [21]
2 Solidification cracking and suitable testing methods

Solidification cracking is a defect connected to the solidification process during fusion welding of metals, caused by a combination of thermomechanical and metallurgical aspects. Certain alloying elements form low-melting phases in which cracks tend to initiate under deformation within a critical temperature range. In consequence, the solidification cracking susceptibility of a material can be described by its so-called brittleness-temperature-range (BTR) [24]. Cracking can only occur if strains within the critical temperature range exceed a certain threshold. The BTR therefore poses a solely materialspecific parameter.

Under certain conditions, residual liquid contents flowing into previously formed cracks during further cooling can result in crack healing $[25,26]$. For example, alloys with a composition close to the eutectic are known for low solidification cracking susceptibilities because of their high potential for crack healing [27].

The connection between primary solidification mode and solidification cracking susceptibility has been the subject of numerous studies. Primary austenitic solidification is known to have a negative influence on a material's cracking susceptibility, and certain constituents of weld-ferrite are known to have a positive effect in this regard [28-30]. Compared with ferritic materials, slower diffusion and lower solubility for alloying elements in austenite promote segregation [26]. Furthermore, austenitic materials feature higher thermal expansion and coincidentally lower thermal conductivity, which also supports solidification cracking [31].

For solidification cracking testing, among other methods, the modified Varestraint/Transvarestraint test (MVT), developed at the Bundesanstalt für Materialforschung und prüfung (BAM) [32], can be used. In this test, cuboid blocks are melted at the surface using a gas tungsten arc welding (GTAW) torch moving along the specimen. During this welding process, the specimen is bent over dies with different radii, length- or crosswise (Fig. 4). Through deformation to specific levels at specific speeds and within the solidification temperature range of the material, the general requirements for solidification cracking are met. Standard test evaluation relies on quantification of surface cracks, which can then be translated into an assessment of solidification cracking susceptibility of the material.

Experience from recent testing shows that some materials, particularly modern high-performance alloys such as LTT, also exhibit cracking in the bulk [20]. In those cases, the standard MVT procedure, which relies on surface cracks, might be insufficient for assessing the cracking susceptibility. The current study therefore aims to extend the evaluation basis to the volume of the specimen, allowing for a more reliable assessment of cracking susceptibility. 
Fig. 2 Weld cross section and microstructure of LTT alloy B [21]

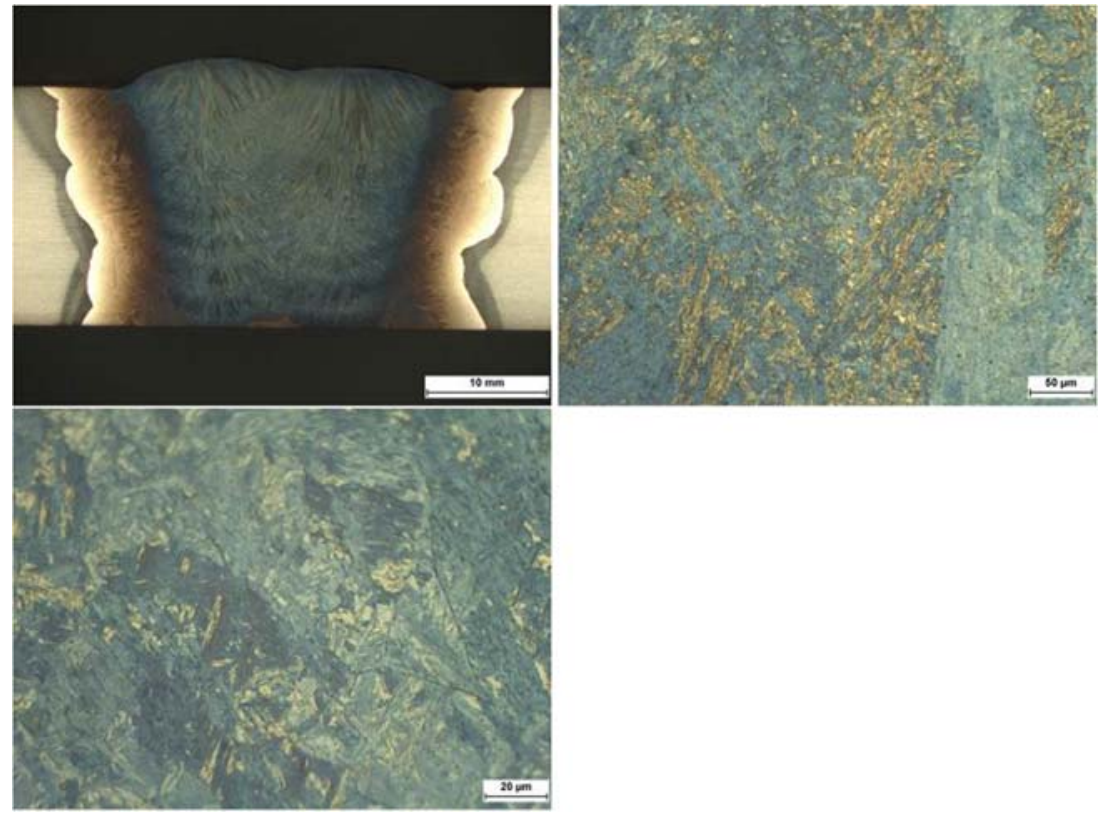

\section{Influence of MVT testing parameters on the solidification cracking susceptibility}

As inherent to the functional principles, applied strain is the key factor influencing the extent of cracking detected in Varestraint testing. Other main influencing parameters are heat input, travel speed, specimen thickness, and stroke rate (bending speed) $[26,33]$.

Numerous studies regarding the direct influence of testing parameters on the results have been conducted in the past, often with diverse results. While the general agreement is that higher strains increase the cracking response [24, 26, 33], contradicting opinions on the influence and general importance of other process parameters can be found in the literature.

Specimen thickness is usually not varied within a series of experiments, but regarded to be a significant influence on test results [34]. This aspect becomes even more complex when considering that nominal applied strain often deviates significantly from the actual local deformations in the vicinity of the weld pool, which pose the critical factor but at the same time are highly inhomogeneous [35].
Fig. 3 Weld cross section and microstructure of LTT alloy G [21]

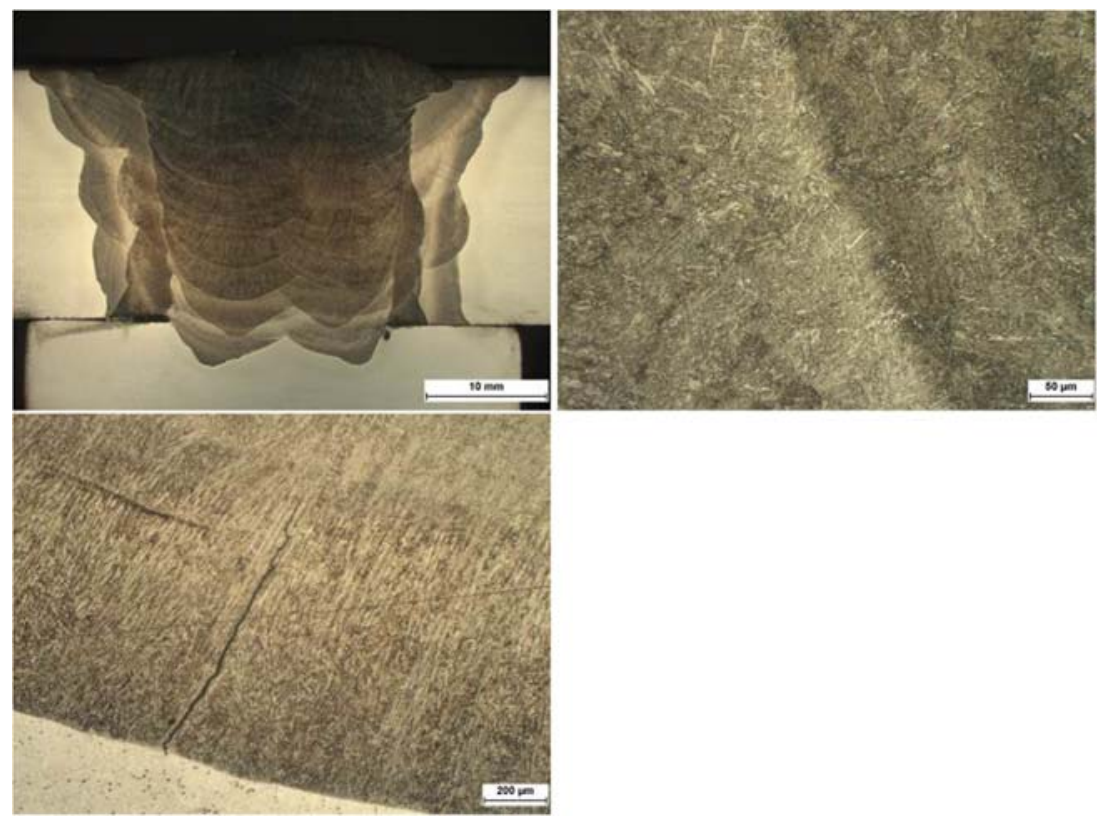


Fig. 4 The modified Varestraint/ Transvarestraint test

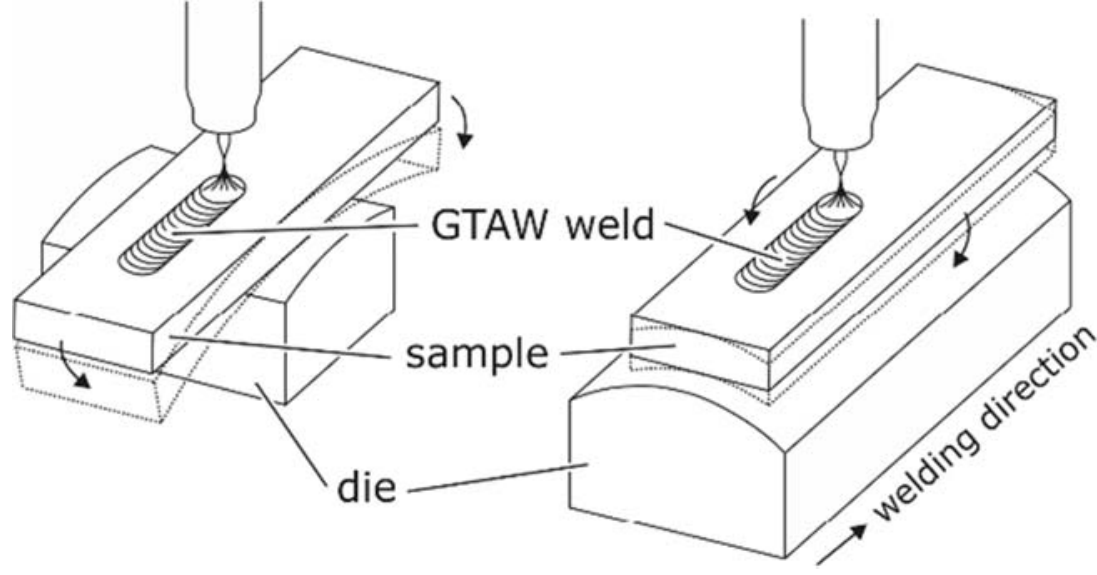

Travel speed has been reported to be the most complex [34] or even critical [36] parameter, said to increase [37] or to decrease [38] cracking under otherwise equal conditions.

Some studies consider stroke rate to be of minor importance [36], while others regard it to be even more critical than travel speed [39]. It is furthermore expected to influence crack lengths due to crack extension during bending [40], and to delimit the amount of strain taking effect during a confined solidification interval [25]. In MVT-specific investigations, stroke rate was even found to have a linear correlation to cracking response, making it an important factor for quantifying cracking. Low stroke rates also appeared to favour centreline cracking, while increased stroke rates caused expansion of the crack afflicted area towards the edges of the weld [31].

In summary, Varestraint testing parameters are generally accepted to have a significant influence on test results, but still there is no general agreement on test specifications. Test results and parameters cannot be compared directly, and apparent contradictions cannot be discussed independently. This problem is further illustrated in Table 1, which is a review of technical standards, recent publications, and selected particularly reputable work, showing how much common Varestraint testing parameters diverge between different testing facilities.

The present study therefore aims to evaluate influences of different Varestraint testing parameters on solidification cracking in LTT alloys of different compositions. As sub-surface cracking has been observed in the past, volume-based analysis methods are to be employed in this regard.

\section{Materials}

Several $\mathrm{Cr} / \mathrm{Ni}$ - and $\mathrm{Cr} / \mathrm{Mn}$-based LTT alloys were used in this study (see Table 2). Alloys A and B contain more $\mathrm{Cr}$ than Ni. In contrast, alloys $\mathrm{C}-\mathrm{F}$ exhibit a higher $\mathrm{Ni}$ content compared with $\mathrm{Cr}$. Alloys $\mathrm{G}$ and $\mathrm{H}$ are $\mathrm{Cr} / \mathrm{Mn}$ alloyed, with $\mathrm{Cr}$ being the main alloying element. Mn shows a lower austenite stabilizing effect compared with $\mathrm{Ni}$; therefore, these wires contain more $\mathrm{Cr}$. Cr alone is ferrite stabilizing, but in combination with $\mathrm{Mn}$ or $\mathrm{Ni}$, it causes a reduction of the $\mathrm{M}_{\mathrm{s}}$ temperature. Variants with higher carbon contents have shown to be particularly susceptible to solidification cracking [20-22] and were therefore used in this study.

The $\mathrm{Cr}, \mathrm{Ni}, \mathrm{Mn}$, and $\mathrm{C}$ contents were adjusted gradually in order to systematically vary the $\mathrm{Cr}_{\mathrm{eq}} / \mathrm{Ni}_{\mathrm{eq}}$ ratios, as shown in Table 2. Other accompanying elements were not varied. The $\mathrm{M}_{\mathrm{s}}$ temperatures have a range of 164 to $297{ }^{\circ} \mathrm{C}$. All fillers were produced as metal-cored wires with a diameter of $1.6 \mathrm{~mm}$.

\section{Experimental}

\subsection{Standard MVT procedure}

In order to apply MVT testing to filler metals, specimens must be made from deposited weld metal. Blank specimens were manufactured from S235 mild steel, featuring a rounded centre groove ( $5 \mathrm{~mm}$ deep, $20 \mathrm{~mm}$ wide, $5 \mathrm{~mm}$ corner radius; see Fig. 5). The groove was then filled with weld metal using gas metal arc welding. This was done in multiple passes in order to avoid any results being corrupted by the properties of the specimen base material. After welding, the specimens were machined and ground to match standard MVT dimensions $(100 \times 40 \times 10 \mathrm{~mm}$; see Fig. 5). During the following actual testing, a moving GTAW torch was melting only the deposited weld metal in the top centre of the specimen.

An investigation on MVT parameter sets outside of the standard range was carried out on alloys $\mathrm{A}$ and $\mathrm{H}$, with a focus on stroke rate and energy input. This was expected to characterize the materials in more detail, therefore helping to find suitable testing parameters for future experiments on similar materials.

Rather, high stroke rates for Varestraint testing are the standard for many testing facilities around the world (see Table 1). 
Table 1 Common Varestraint test parameter sets found in the literature

\begin{tabular}{|c|c|c|c|c|c|c|c|c|}
\hline Source & $\begin{array}{l}\text { Current } \\
\text { (A) }\end{array}$ & $\begin{array}{l}\text { Voltage } \\
\text { (V) }\end{array}$ & $\begin{array}{l}\text { Travel } \\
\text { speed } \\
(\mathrm{cm} / \mathrm{min})\end{array}$ & $\begin{array}{l}\text { Energy } \\
\text { input } \\
(\mathrm{kJ} / \mathrm{cm})\end{array}$ & $\begin{array}{l}\text { Stroke rate } \\
(\mathrm{mm} / \mathrm{s})\end{array}$ & $\begin{array}{l}\text { Strain } \\
(\%)\end{array}$ & $\begin{array}{l}\text { Magnification } \\
\text { (optical } \\
\text { microscope) }\end{array}$ & $\begin{array}{l}\text { Specimen } \\
\text { thickness } \\
(\mathrm{mm})\end{array}$ \\
\hline ISO TR 17641-3 [41] & 85 & 12.5 & 18 & 3.54 & $>1.8$ & $\mathrm{n} / \mathrm{a}$ & 25 & 10 \\
\hline ISO TR 17641-3 [41] & 220 & 13.5 & 11 & 16.20 & $>1.8$ & $\mathrm{n} / \mathrm{a}$ & 25 & 10 \\
\hline ANSI AWS B4.0:2016 [42] & $\mathrm{n} / \mathrm{a}$ & $\mathrm{n} / \mathrm{a}$ & $\mathrm{n} / \mathrm{a}$ & $\mathrm{n} / \mathrm{a}$ & $\mathrm{n} / \mathrm{a}$ & $0-4$ & $40-80$ & $3-10$ \\
\hline BAM Standard no. 1 & 190 & 12 & 18 & 7.60 & 2 & $0-4$ & 25 & 10 \\
\hline BAM Standard no. 2 & 210 & 12.7 & 10.8 & 14.82 & 2 & $0-4$ & 25 & 10 \\
\hline Zhu et al. [43] & 150 & 17 & 10 & 15.30 & $\mathrm{n} / \mathrm{a}$ & $0-6$ & $\mathrm{n} / \mathrm{a}$ & 6 \\
\hline Statharas et al. [44] & 225 & 12 & 21 & 7.71 & $\mathrm{n} / \mathrm{a}$ & $2-11$ & $\mathrm{n} / \mathrm{a}$ & 24 \\
\hline Singh et al. [45] & 180 & 10 & 13 & 0.80 & 1 & 5 & $\mathrm{n} / \mathrm{a}$ & 5 \\
\hline Abe et al. [46] & 200 & 14.3 & 16 & 10.73 & 150 & $1.96-5.88$ & $\mathrm{n} / \mathrm{a}$ & 10 \\
\hline Singh et al. [47] & 70 & $\mathrm{n} / \mathrm{a}$ & 6 & $\mathrm{n} / \mathrm{a}$ & 10 & $0.8-8.2$ & $\mathrm{n} / \mathrm{a}$ & 3.3 \\
\hline Lippold [26] & $160-190$ & $\mathrm{n} / \mathrm{a}$ & $10.2-15$ & $\mathrm{n} / \mathrm{a}$ & $152-254$ & $0.5-7$ & $20-50$ & 6.35 \\
\hline Srinivasan et al. [48] & 90 & 11.5 & 25.2 & 2.46 & $\begin{array}{l}\text { Within } \\
0.015 \mathrm{~s}\end{array}$ & $0.25-4$ & 60 & 3 \\
\hline Andersson et al. [36] & $70-90$ & $\mathrm{n} / \mathrm{a}$ & $6-18$ & $\mathrm{n} / \mathrm{a}$ & $10-250$ & $2.7-4$ & $\mathrm{n} / \mathrm{a}$ & 3.2 \\
\hline Yushchenko et al. [49] & 90 & 9.7 & 4.8 & 10.91 & $\mathrm{n} / \mathrm{a}$ & $0.2-2$ & 50 & 3.5 \\
\hline Lundin et al. [34] & 190 & $\mathrm{n} / \mathrm{a}$ & 12.7 & $\mathrm{n} / \mathrm{a}$ & Within $0.1 \mathrm{~s}$ & $0-4$ & $40-80$ & 7.925 \\
\hline Arata et al. [50] & 250 & 17 & 10 & 25.50 & $\mathrm{n} / \mathrm{a}$ & $0.2-4$ & 40 & 12 \\
\hline Senda et al. [51] & 250 & 18 & 15 & 18.00 & $170-250$ & $0.15-1.5$ & $42-100$ & $6-9$ \\
\hline
\end{tabular}

However, high stroke rates have been reported to supress potential back-filling of cracks, making Varestraint testing less suitable for assessment of materials which might exhibit crack healing $[52,53]$. Testing at different strain rates was therefore carried out in search for further insight into the crack healing potentials of the examined materials. In order to provide for comparability to previous studies at BAM, the current study uses a default stroke rate of $2 \mathrm{~mm} / \mathrm{s}$. Additional experiments were set at stroke rates of $0.2 \mathrm{~mm} / \mathrm{s}$ and $6 \mathrm{~mm} / \mathrm{s}$, which is relating to the minimum and maximum machine settings.

Table 3 shows the range of parameters covered by the experiments. For the main set of experiments, 46 specimens

Table 2 Chemical composition of the LTT alloys used in this study, determined by spectral analysis (wt\%)

\begin{tabular}{lllllllll}
\hline Type & key & C & Cr & Ni & Mn & Fe & $\begin{array}{c}\mathrm{Cr}_{\text {eql }}{ }^{2} \\
\mathrm{Ni}_{\text {eq }}\end{array}$ & $\begin{array}{l}\mathrm{M}_{\mathrm{s}} \text { in } \\
{ }^{\circ} \mathrm{C}\end{array}$ \\
\hline $\mathrm{CrNi}$ & $\mathrm{A}$ & 0.05 & 7.48 & 6.05 & 0.47 & bal. & 0.98 & 297 \\
$\mathrm{CrNi}$ & $\mathrm{B}$ & 0.07 & 7.41 & 6.08 & 0.49 & bal. & 0.90 & 275 \\
$\mathrm{CrNi}$ & $\mathrm{C}$ & 0.07 & 6.30 & 7.90 & 0.56 & bal. & 0.61 & $268^{\mathrm{b}}$ \\
$\mathrm{CrNi}$ & $\mathrm{D}$ & 0.09 & 7.10 & 8.20 & 0.60 & bal. & 0.64 & $238^{\mathrm{b}}$ \\
$\mathrm{CrNi}$ & $\mathrm{E}$ & 0.10 & 6.80 & 7.70 & 0.60 & bal. & 0.63 & $247^{\mathrm{b}}$ \\
$\mathrm{CrNi}$ & $\mathrm{F}$ & 0.11 & 6.50 & 7.90 & 0.59 & bal. & 0.56 & $245^{\mathrm{b}}$ \\
$\mathrm{CrMn}$ & $\mathrm{G}$ & 0.07 & 11.90 & 0.02 & 5.40 & bal. & 2.47 & 164 \\
$\mathrm{CrMn}$ & $\mathrm{H}$ & 0.03 & 11.40 & 0.02 & 5.00 & bal. & 3.28 & 176 \\
\hline
\end{tabular}

${ }^{\text {a }}$ Calculated as follows: $\mathrm{Cr}_{\mathrm{eq}}=\mathrm{Cr}, \mathrm{Ni}_{\mathrm{eq}}=\mathrm{Ni}+30 \mathrm{C}+0.5 \mathrm{Mn}$

${ }^{\mathrm{b}}$ Calculated after [23] made from alloy A and alloy $\mathrm{H}$ filler metals each (92 in total) were processed in 10 Varestraint and 10 Transvarestraint tests each, with 2-3 specimens per parameter set. From all other alloys, 2 specimens each were tested at $7.5 \mathrm{~kJ}, 2 \mathrm{~mm} / \mathrm{s}$ stroke rate, and $4 \%$ strain. After testing, following the standard MVT analysis procedure, the specimens were examined by capturing the surface cracks that are visible at $\times 25$ magnification through an optical microscope.

\section{$5.2 \mu \mathrm{CT}$ approach}

The standard MVT analysis does not consider sub-surface cracking. Hence, for a more complete and accurate assessment

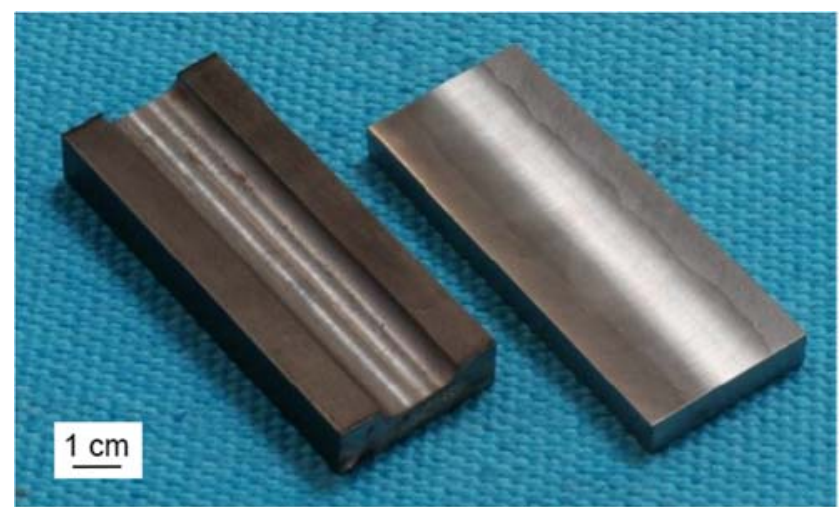

Fig. 5 MVT specimens before deposition of weld metal (left) and after finishing, ready to test (right) 
Table 3 Range of MVT testing parameters used in the current study

\begin{tabular}{lcc}
\hline Energy input $(\mathrm{kJ} / \mathrm{cm})$ & 7.5 & 15 \\
\hline Current $(\mathrm{A})$ & 190 & 210 \\
Voltage $(\mathrm{V})$ & 11.84 & 12.86 \\
Travel speed $(\mathrm{mm} / \mathrm{s})$ & 3 & 1.8 \\
Test mode & Varestraint/Transvarestraint \\
Stroke rate $(\mathrm{mm} / \mathrm{s})$ & $0.2 / 2 / 6$ & \\
Strain & $1 \% / 4 \%$ & \\
\hline
\end{tabular}

of cracking susceptibility, volume information should also be considered. Therefore, microfocus X-ray computer tomography $(\mu \mathrm{CT})$ was applied to crack afflicted areas of selected specimens at Karlsruhe Institute of Technology (KIT) using the high-resolution cone-beam CT system type Yxlon Y.CT Precision with fine focus twin head FXE 225.99. These scans were performed at a high voltage of $190 \mathrm{kV}$ and $0.06 \mathrm{~mA}$. This allows characteristics of the complete $3 \mathrm{D}$ crack network to be extracted.

The first step during $\mu \mathrm{CT}$ analysis consisted of scanning each specimen as a whole, in order to locate the area of interest for exact quantification of volume cracking. This provides a good overview of crack afflicted areas, which after localization can be physically extracted from the large specimens. The now considerably reduced absorption thickness (about $10 \mathrm{~mm}$ ) leads to significantly improved image qualities. As the smaller specimens can also be positioned closer to the Xray source, spatial resolution of the reconstructed $3 \mathrm{D}$ images is improved due to the cone-beam geometry (uncut specimens $25 \mu \mathrm{m}$ voxel size, cut specimens $\sim 7 \mu \mathrm{m}$ voxel size). At this point, the obtained image quality is still not sufficient for reliable and fast segmentation of the cracks using commercially available software. In this regard, a two-step segmentation strategy was implemented. In the first step, an adaptive thresholding algorithm (described in [54]) was applied. Here, the 3D image is partitioned into small cubes with defined edge length. Within the cuboids, a mean local grey value is calculated. If the grey value of a voxel is below a certain threshold of the mean grey value (e.g. 10\%), this voxel is detected as a crack. The adaptive thresholding algorithm allows handling of the large grey value fluctuations within the reconstructed 3D specimen volume. In the second step, the segmented voxels from the first step are used as the so called seeds for a region growing algorithm [55]. This segmentation strategy examines neighbouring voxels of the initial "seeds" and determines by means of a second threshold whether they should be added to the crack region or not. Using the region growing algorithm allows the growing or shrinking of the detected cracks to their final size. Subsequently, the segmented binary images are analyzed statistically and quantitatively. Therefore, the 3D crack network is described in regard to e.g. crack volume, cracking surface, crack length over depth, crack orientation, or degree of branching.

The $\mu \mathrm{CT}$ analysis procedure takes about $6 \mathrm{~h}$ in total per specimen, including specimen preparation (cutting), $2 \mathrm{~h}$ of scan time, and data evaluation.

\section{Results}

\subsection{Standard MVT analysis}

A variation of total strain was performed for alloys $\mathrm{A}(\mathrm{CrNi}$ type) and $\mathrm{H}$ (CrMn type). For both alloys, strains of $1 \%$ did not result in any cracking. Further increasing of the strain to $4 \%$ caused cracks to form, to different extents. Therefore, only experiments set at $4 \%$ strain will be considered below.

In the same way, no cracks could be detected for stroke rates of $0.2 \mathrm{~mm} / \mathrm{s}$, regardless of material composition or other process parameters. Thus, only experiments at stroke rates of $2 \mathrm{~mm} / \mathrm{s}$ or above will be considered from here on.

All observed cracks were located within the weld and identified as solidification cracks. Their exact location varies slightly between Varestraint and Transvarestraint tests, with the former producing a more spread-out crack pattern, while the latter favoured cracks closer to the weld centreline. The degree of surface cracking is herein after assessed by means of total crack length (TCL), which was measured according to the MVT standard analysis procedure.

Figure 6 shows the total crack lengths for all alloys at $7.5 \mathrm{~kJ} / \mathrm{cm}$ energy input, $2 \mathrm{~mm} / \mathrm{s}$ stroke rate, and $4 \%$ strain. Among all alloys, the $\mathrm{CrMn}$ types $(\mathrm{G}$ and $\mathrm{H})$ show the lowest extent of cracking. CrNi-type alloys $\mathrm{B}$ and $\mathrm{C}$ exhibit around $4 \mathrm{~mm}$ TCL; all other alloys are above $9.88 \mathrm{~mm}$ TCL.

The influence of different MVT testing parameter sets on the results was investigated for alloys $\mathrm{A}$ and $\mathrm{H}$; results are shown in Fig. 7. Contradicting trends were found concerning the effects of energy input and stroke rate.

Alloy A shows a considerable degree of cracking for lower energy input in Varestraint tests at $2 \mathrm{~mm} / \mathrm{s}$ stroke rate, while at high energy input, almost no cracking occurs. Increasing the stroke rate to $6 \mathrm{~mm} / \mathrm{s}$ practically levels the influence of energy input. Transvarestraint testing produces very uniform results for all parameter sets. Just as in the Varestraint tests, lower energy input causes higher cracking response, although the difference is far more subtle. In general, however, neither energy input nor stroke rate seems to have significant influence on the Transvarestraint test results, as the TCL remains at a very similar level.

The Varestraint results for $2 \mathrm{~mm} / \mathrm{s}$ stroke rate and $7.5 \mathrm{~kJ} / \mathrm{cm}$ energy input seemed out of line with the general trends. In order to validate the results in question, an additional experiment was carried out later on as a follow-up to the original experimental plan. Three specimens were tested at $10 \mathrm{~kJ} / \mathrm{cm}$ 


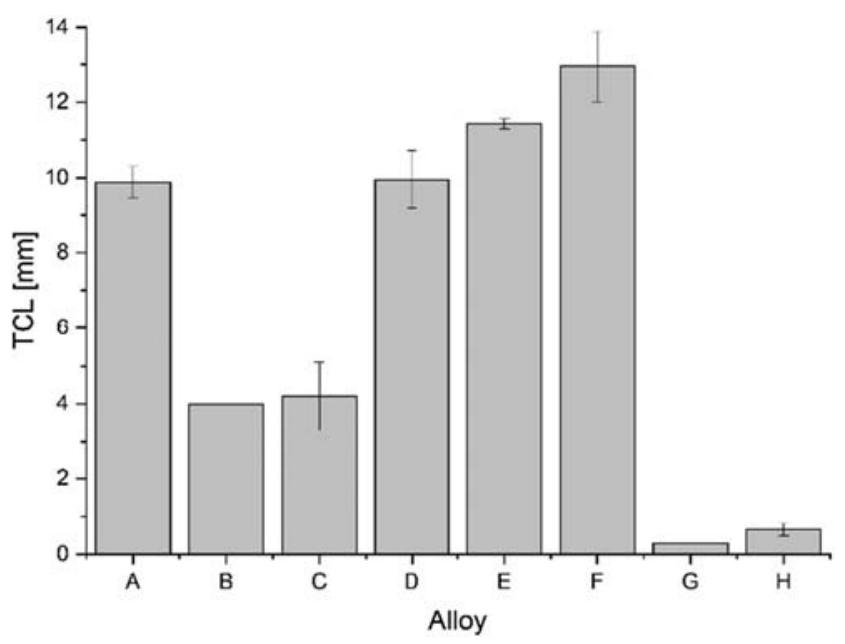

Fig. 6 Total crack lengths (TCL) for alloys A through $\mathrm{H}(7.5 \mathrm{~kJ} / \mathrm{cm}$ energy input, $2 \mathrm{~mm} / \mathrm{s}$ stroke rate, and $4 \%$ strain)

energy input $(2.4 \mathrm{~mm} / \mathrm{s}$ travel speed, $200 \mathrm{~A}), 4 \%$ strain, and $2 \mathrm{~mm} / \mathrm{s}$ stroke rate. The result falls right in between the other data points.

Alloy $\mathrm{H}$ shows a much more consistent response to different testing parameters, and no qualitative difference between Varestraint and Transvarestraint modes. Higher energy input generally causes a higher degree of cracking, regardless of stroke rate. Higher stroke rates cause a significant but non-
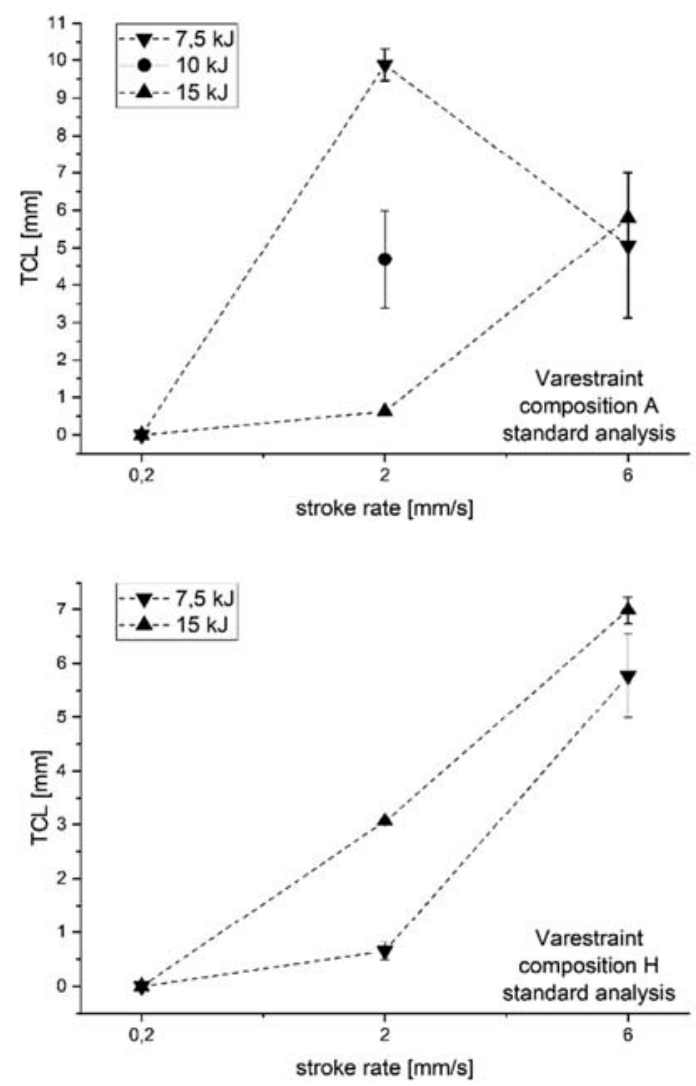

linear increase in cracking. This seems to reduce the influence of energy input, as the TCL at different energy inputs converges for higher stroke rates.

Metallographic cross sections for alloys $\mathrm{A}$ and $\mathrm{H}$ are shown in Fig. 8. It can be seen that alloy A is exhibiting a considerable amount of cracking below the surface, while cracks in alloy $\mathrm{H}$ generally tend to propagate to the specimen surface, displaying an amount of visible cracking that is more in proportion to crack volume below the surface.

\section{$6.2 \mu \mathrm{CT}$ analysis approach}

In order to address the different behaviours concerning crack propagation into the bulk (Fig. 8), further investigation in this regard was conducted on all alloys using $\mu \mathrm{CT}$ analysis. Unfortunately, due to inadequate specimen preparation, no results could yet be obtained for alloy D.

Figure 9a shows TCL at different depths for alloys $\mathrm{C}$ and $\mathrm{E}$, calculated from $\mu \mathrm{CT}$ scans. It can be seen that the total crack length at the surface $(0 \mathrm{~mm}$ depth) is very similar, around $2.5 \mathrm{~mm}$ for both materials. However, cracks in alloy $\mathrm{E}$ reach much deeper into the specimen volume than in alloy $\mathrm{C}$, around $3.0 \mathrm{~mm}$ versus $2.5 \mathrm{~mm}$, respectively.

Even more significant differences become apparent when comparing alloy B and C weld metals (Fig. 9b), featuring $2.6 \mathrm{~mm}$ and $0.75 \mathrm{~mm}$ total crack length at the surface,
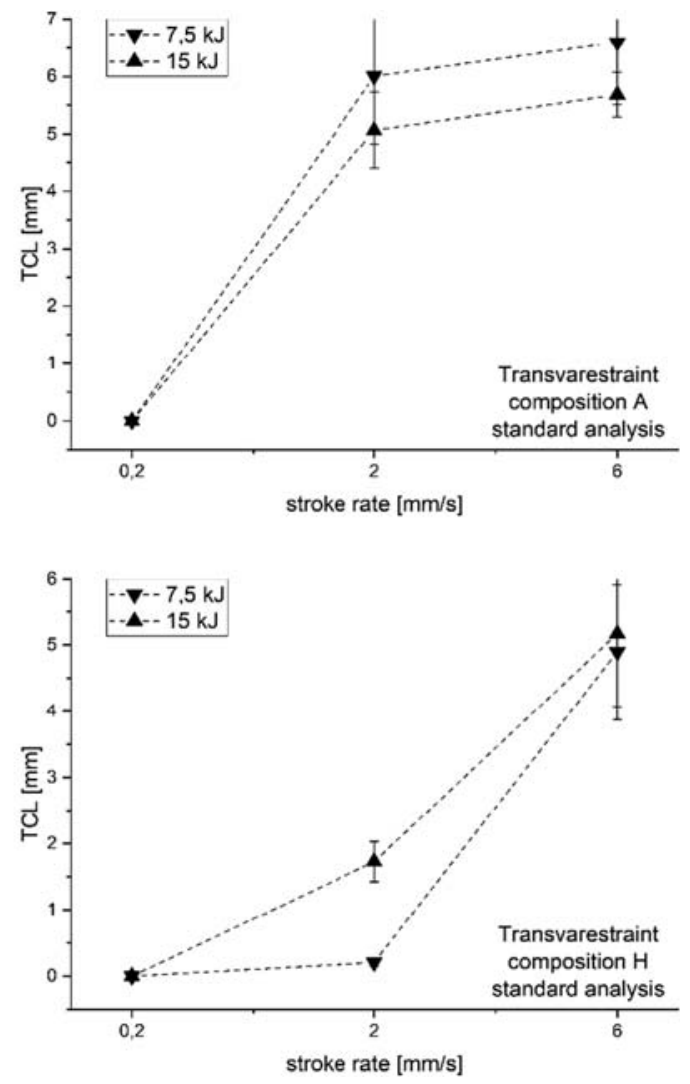

Fig. 7 Total crack lengths (TCL) for alloys $\mathrm{A}$ and $\mathrm{H}$ at $4 \%$ strain for different energy inputs and different stroke rates 


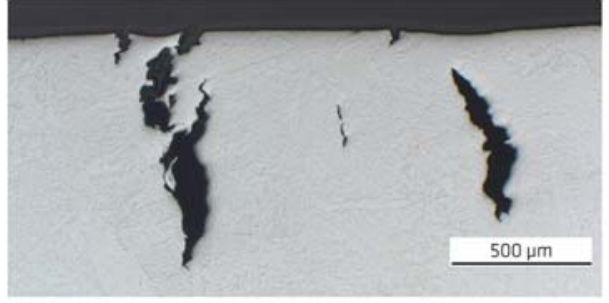

a)

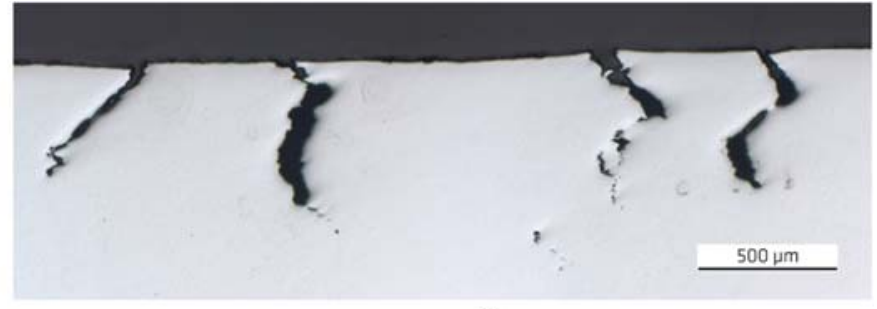

b)

Fig. 8 Solidification cracks in alloy A (a) and $\mathrm{H}$ (b) from Transvarestraint specimens tested at $4 \%$ strain, $15 \mathrm{~kJ} / \mathrm{cm}$ energy input, and $6 \mathrm{~mm} / \mathrm{s}$ stroke rate; cross sections were taken from the crack afflicted areas in the specimen centre, normal to the welding path

respectively. Looking into the volume, cracks in alloy B reach deeper than in alloy $\mathrm{C}(2.8 \mathrm{~mm}$ versus $2.5 \mathrm{~mm})$, even though surface-based evaluation clearly presents alloy B to be less prone to cracking.

Investigations on CrMn-type alloys turned out to be more challenging, as both alloys $\mathrm{G}$ and $\mathrm{H}$ exhibit very little cracking. In addition, the morphology of crack networks is considerably finer than for CrNi-type alloys, making them increasingly difficult to detect. For the case of alloy $\mathrm{H}$, no cracks could be found in the $\mu \mathrm{CT}$ investigations, while the standard analysis clearly showed surface cracking, albeit at a very low level (see Fig. 11).

\section{Discussion}

Higher energy inputs were expected to have a negative effect on the degree of solidification cracking. In the case of alloy $\mathrm{H}$, this is reflected by the MVT standard analysis results. Alloy A exhibits an entirely different behaviour, with crack length decreasing at increased energy input. Due to the different nature of the two alloy types (CrMn and $\mathrm{CrNi}$, respectively), further examination of the solidification characteristics and the specimen volumes was expected to generate more insight.

In accordance with analytic calculations after Hull [56] and Hammar and Svensson [57], the WDX analysis of alloy A and alloy $\mathrm{H}$ filler metals indicates different primary solidification modes. The microstructure of alloy $\mathrm{A}\left(\mathrm{Cr}_{\mathrm{eq}} / \mathrm{Ni}_{\mathrm{eq}}=0.98\right)$ is marked by concordant distribution of $\mathrm{Cr}$ and $\mathrm{Ni}$ (Fig. 10a), which is typical for austenitic primary solidification. The alloy $\mathrm{H}$ weld metal $\left(\mathrm{Cr}_{\mathrm{eq}} / \mathrm{Ni}_{\mathrm{eq}}=3.28\right)$ on the other hand exhibits discordant distribution of $\mathrm{Cr}$ and $\mathrm{Mn}$ (Fig. 10b), indicating ferritic primary solidification $[28,58]$.

Crack volume determined in $\mu \mathrm{CT}$ analysis on MVT specimens is shown in Fig. 11 for all alloys as a function of their $\mathrm{Cr}_{\mathrm{eq}} / \mathrm{Ni}_{\mathrm{eq}}$ ratios (blue line, alloys from left to right: $\mathrm{F}, \mathrm{C}, \mathrm{E}, \mathrm{B}, \mathrm{A}, \mathrm{G}, \mathrm{H})$. It can be seen that with increasing $\mathrm{Cr}_{\text {eq }} / \mathrm{Ni}_{\text {eq }}$ ratio, the crack volume decreases. For $\mathrm{Cr}_{\mathrm{eq}} \mathrm{Ni}_{\mathrm{eq}}$ ratios of 3 and above, no cracks are found, while a peak level of around $3.3 \mathrm{~mm}^{3}$ is reached for $\mathrm{Cr}_{\mathrm{eq}}$ ' $\mathrm{Ni}_{\text {eq }}$ ratios between 0.55 and 0.62 . The reason for this is expected to be the austenitic primary solidification mode prevailing for $\mathrm{Cr}_{\mathrm{eq}} / \mathrm{Ni}_{\mathrm{eq}}$ ratios $<1.5$. This level has been reported to be a threshold above which a minimum cracking susceptibility is to be expected in the case of stainless steels $[28,59]$.

Figure 11 furthermore shows a comparison between total crack length found in MVT standard analysis and crack volume found in $\mu \mathrm{CT}$ analysis, again referenced to the corresponding $\mathrm{Cr}_{\mathrm{eq}} / \mathrm{Ni}_{\mathrm{eq}}$ ratios (red line, alloys from left to right: F, C, E, D, B, A, G, H). While the results from both analysis methods match the presumed coherence between cracking
Fig. 9 Total crack length as a function of depth, evaluated using $\mu \mathrm{CT}$ analysis for alloy $\mathrm{C}$ and $\mathrm{E}$ weld metals (a), as well as alloys $\mathrm{B}$ and $\mathrm{C}(\mathbf{b})$

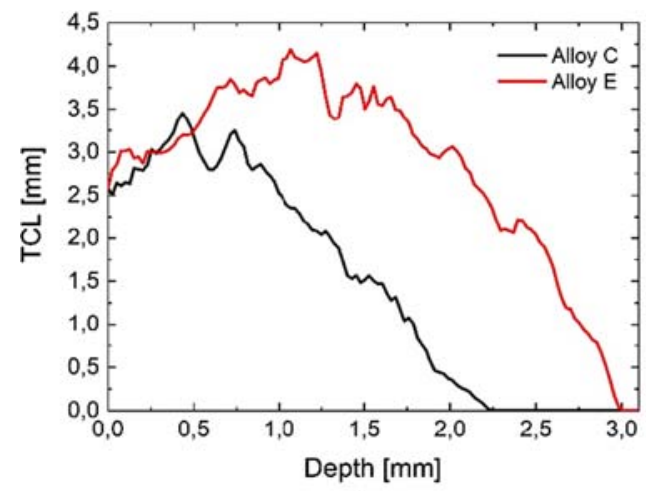

a)

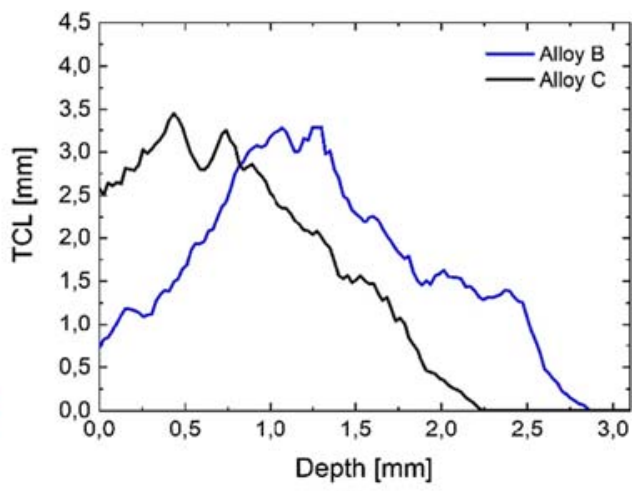

b) 


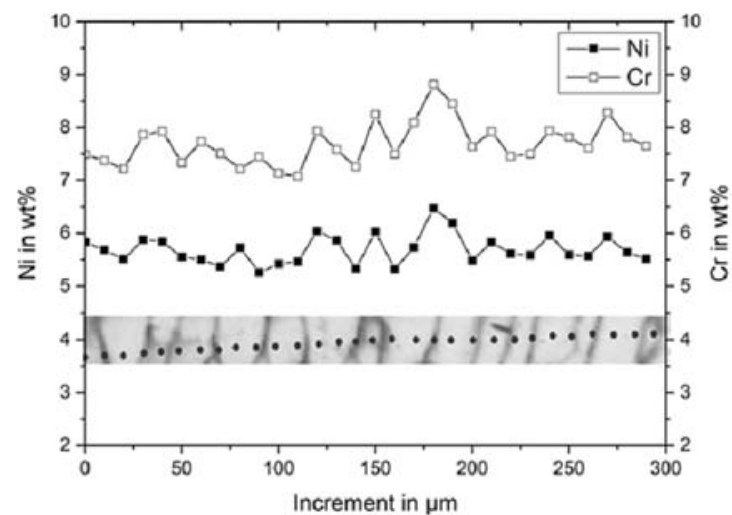

a)

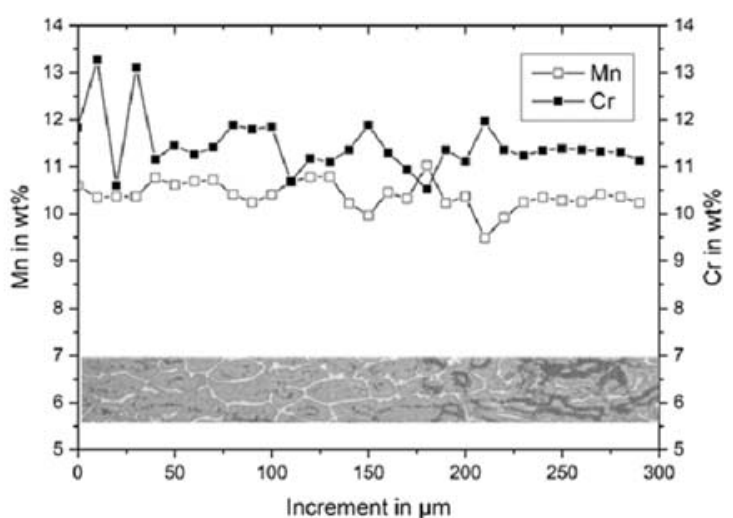

b)

Fig. 10 Element distribution of $\mathrm{Ni}$ and $\mathrm{Cr}(\mathbf{a})$, as well as $\mathrm{Cr}$ and $\mathrm{Mn}(\mathbf{b})$ in alloy A and alloy H, respectively (WDX analysis)

response and $\mathrm{Cr}_{\mathrm{eq}} / \mathrm{Ni}_{\mathrm{eq}}$ ratio, there is a more consistent trend for the $\mu \mathrm{CT}$ results. This is attributed to the significant amount of cracking in the specimen volume which was observed for CrNi-type alloys (see Fig. 8) but is not considered in the standard analysis process. Therefore, assessment of cracking susceptibility based on 3D crack networks brings a considerable added benefit over the conventional, surface-based analysis procedures.

Regarding the variation of testing parameters which was carried out for alloys $\mathrm{A}$ and $\mathrm{H}$, different factors were found to trigger cracking. For the case of alloy A, cracking is substantially favoured by low energy inputs. $\mu \mathrm{CT}$ analysis is able to back up this finding. This behaviour was attributed to conflicting influences of weld pool geometry and solidification characteristics for varying energy inputs or welding speeds [60], yet additional investigations are required to fully explain these results. Cracking in alloy $\mathrm{H}$ was found to be triggered by higher stroke rates. The reason for this is believed to be the alloy's considerable ability to back-fill existing cracks, given

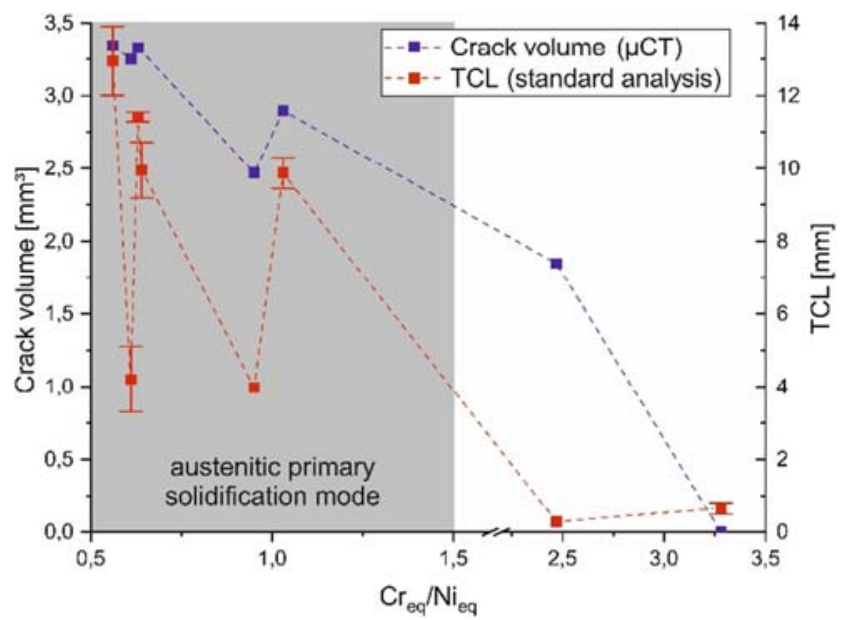

Fig. 11 Crack volume determined in $\mu \mathrm{CT}$ and total crack length determined in standard MVT testing (energy input $7.5 \mathrm{~kJ} / \mathrm{cm}$, stroke rate $2 \mathrm{~mm} / \mathrm{s}, 4 \%$ strain) as a function of $\mathrm{Cr}_{\mathrm{eq}} / \mathrm{Ni}_{\mathrm{eq}}$ that there is enough time. This also explains why regardless of any other parameters, no cracking was observed for the extremely low stroke rate of $0.2 \mathrm{~mm} / \mathrm{s}$.

\section{Summary and conclusions}

Different CrNi- and CrMn-type LTT filler metals were examined regarding their solidification cracking susceptibility. In addition to standard Varestraint analysis methods, a $\mu \mathrm{CT}$ approach was used to quantify cracking in the specimen volume. The following conclusions can be drawn:

- Most of the evaluated alloys showed significant, yet varying extents of cracking in the specimen volume. Surfacebased analysis methods therefore entail inaccurate representation of cracking susceptibilities. Volume-based examination should be used for better quantification in these cases.

- The $\mu \mathrm{CT}$ analysis approach discussed in this study was proven to be a suitable method for more accurate, volumebased specimen evaluation.

- With increasing $\mathrm{Cr}_{\mathrm{eq}} / \mathrm{Ni}_{\mathrm{eq}}$ ratios, the 3D crack networks become increasingly finer in morphology. Because of its resolution limit, the $\mu \mathrm{CT}$ analysis in its current state of development works best on those LTT alloys with $\mathrm{Cr}_{\mathrm{eq}}$ / $\mathrm{Ni}_{\mathrm{eq}}$ ratios of 2.5 or below.

- The evaluated alloys with a $\mathrm{Cr}_{\mathrm{eq}} / \mathrm{Ni}_{\mathrm{eq}}$ ratio of 1.5 or lower show the highest cracking susceptibility, which is in good agreement with the literature on common stainless steels.

- The CrNi-type alloy A is almost insensitive to differences in stroke rate but decreasing energy input favours cracking. Additional specimens need to be tested in order to back up and explain this finding in more detail.

- Cracking of the CrMn-type alloy $\mathrm{H}$ is predominantly triggered by increasing stroke rates, which is attributed to a higher potential for crack healing. 
- Common Varestraint test parameters are highly inconsistent, yet different material characteristics might call for more specific test conditions in certain cases. As some of the investigated materials seem to bear considerable potential for crack healing, an adjusted variation of stroke rates shall be used in future investigations on this matter.

Funding information Open Access funding provided by Projekt DEAL. This research received financial support from the German Research Foundation (DFG) in the projects GI376/8-1, KA1807/9-1, and KR3917/2-2.

Open Access This article is licensed under a Creative Commons Attribution 4.0 International License, which permits use, sharing, adaptation, distribution and reproduction in any medium or format, as long as you give appropriate credit to the original author(s) and the source, provide a link to the Creative Commons licence, and indicate if changes were made. The images or other third party material in this article are included in the article's Creative Commons licence, unless indicated otherwise in a credit line to the material. If material is not included in the article's Creative Commons licence and your intended use is not permitted by statutory regulation or exceeds the permitted use, you will need to obtain permission directly from the copyright holder. To view a copy of this licence, visit http://creativecommons.org/licenses/by/4.0/.

\section{References}

1. Ooi SW, Garnham JE, Ramjaun TI (2014) Review: low transformation temperature weld filler for tensile residual stress reduction. Mater Design 56:773-781. https://doi.org/10.1016/j.matdes.2013. 11.050

2. Kromm A, Dixneit J, Kannengiesser T (2014) Residual stress engineering by low transformation temperature alloys-state of the art and recent developments. Weld World 58(5):729-741. https://doi. org/10.1007/s40194-014-0155-6

3. Harati E, Karlsson L, Svensson LE, Pirling T, Dalaei K (2017) Neutron diffraction evaluation of near surface residual stresses at welds in $1300 \mathrm{MPa}$ yield strength steel. Materials 10(6). https://doi. org/10.3390/ma10060593

4. Shiga C, Yasuda HY, Hiraoka K, Suzuki H (2010) Effect of Ms temperature on residual stress in welded joints of high-strength steels. Weld World 54(3-4):R71-R79

5. Dixneit J, Kromm A, Hannemann A, Friedersdorf P, Kannengiesser T, Gibmeier J (2016) In-situ load analysis in multi-run welding using LTT filler materials. Weld World 60(6):1159-1168. https:// doi.org/10.1007/s40194-016-0373-1

6. Dai H, Francis JA, Stone HJ, Bhadeshia H, Withers PJ (2008) Characterizing phase transformations and their effects on ferritic weld residual stresses with X-rays and neutrons. Metall Mater Trans A 39A(13):3070-3078. https://doi.org/10.1007/s11661-0089616-0

7. Shiga C, Murakawa H, Hiraoka K, Osawa N, Yajima H, Tanino T, Tsutsumi S, Fukui T, Sawato H, Kamita K, Matsuzaki T, Sugimura T, Asoda T, Hirota K (2017) Elongated bead weld method for improvement of fatigue properties in welded joints of ship hull structures using low transformation temperature welding materials. Weld World 61(4):769-788. https://doi.org/10.1007/s40194-0170439-8

8. Harati E, Svensson LE, Karlsson L (2017) Improving fatigue strength of welded $1300 \mathrm{MPa}$ yield strength steel using HFMI treatment or LTT fillers. Eng Fail Anal 79:64-74. https://doi.org/ 10.1016/j.engfailanal.2017.04.024

9. Wu SP, Wang DP, Di XJ, Zhang Z, Feng ZY, Liu XQ, Li YZ, Meng XQ (2018) Toughening mechanisms of low transformation temperature deposited metals with martensite-austenite dual phases. J Mater Sci 53(5):3720-3734. https://doi.org/10.1007/s10853-017$1766-2$

10. Feng ZY, Di XJ, Wu SP, Zhang Z, Liu XQ, Wang DP (2018) Comparison of two types of low-transformation-temperature weld metals based on solidification mode. Sci Technol Weld Join 23(3): 241-248. https://doi.org/10.1080/13621718.2017.1376792

11. Di XJ, Geng DD, Wu SP, Wang DP, Zhang Z, Li CN (2019) Solidification behaviour and microstructure of welding transition zone using low-transformation-temperature welding consumables. Sci Technol Weld Join 24(2):148-155. https://doi.org/10.1080/ 13621718.2018.1494403

12. Wu SP, Wang DP, Zhang Z, Li CN, Liu XG, Meng XQ, Feng ZY, Di XJ (2019) Mechanical properties of low-transformationtemperature weld metals after low-temperature postweld heat treatment. Sci Technol Weld Join 24(2):112-120. https://doi.org/10. 1080/13621718.2018.1492776

13. Chen XZ, Wang PF, Pan QH, Lin SB (2018) The effect of martensitic phase transformation dilation on microstructure, strain-stress and mechanical properties for welding of high-strength steel. Crystals 8(7). https://doi.org/10.3390/cryst8070293

14. Wang H, Woo W, Kim DK, Em V, Lee SY (2018) Effect of chemical dilution and the number of weld layers on residual stresses in a multi-pass low-transformation-temperature weld. Mater Design 160:384-394. https://doi.org/10.1016/j.matdes.2018.09.016

15. Novotny L, de Abreu HFG, de Miranda HC, Beres M (2016) Simulations in multipass welds using low transformation temperature filler material. Sci Technol Weld Join 21(8):680-687. https:// doi.org/10.1080/13621718.2016.1177989

16. Dixneit J, Kromm A, Boin M, Wimpory RC, Kannengiesser T, Gibmeier J, Schroepfer D (2017) Residual stresses of LTT welds in large-scale components. Weld World 61(6):1089-1097. https:// doi.org/10.1007/s40194-017-0502-5

17. Jiang W, Chen W, Woo W, Tu S-T, Zhang X-C, Em V (2018) Effects of low-temperature transformation and transformationinduced plasticity on weld residual stresses: numerical study and neutron diffraction measurement. Mater Des 147:65-79

18. Moat R, Ooi S, Shirzadi A, Dai H, Mark A, Bhadeshia H, Withers P (2018) Residual stress control of multipass welds using low transformation temperature fillers. Mater Sci Technol Lond 34(5):519528

19. Reisgen U, Olschok S, Sharma R, Gach S (2017) Influence on martensite-start-temperature and volume expansion of lowtransformation-temperature materials used for residual stress relief in beam welding. Mater Werkst 48(12):1276-1282. https://doi.org/ 10.1002/mawe. 201700160

20. Kannengiesser T, Rethmeier M, Portella P, Ewert U, Redmer B (2011) Assessment of hot cracking behaviour in welds. Int J Mater Res 8(102):6

21. Kromm A, van der Mee V, Kannengiesser T, Kalfsbeek B (2015) Properties and weldability of modified low transformation temperature filler wires. Weld World 59(3):413-425. https://doi.org/10. 1007/s40194-014-0215-y

22. Vollert F, Dixneit J, Gibmeier J (2018) Effect of residual stress relaxation due to sample extraction on the detectability of hot crack networks in LTT welds by means of $\mu$ CT. Mater Res Proc 4:85-90. https://doi.org/10.21741/9781945291678-13

23. Steven WH, A.G. (1956) The temperature of formation of martensite and bainite in low alloy steels, some effects of chemical composition. J Iron Steel Inst 183:349-359

24. Prokhorov N (1962) The technological strength of metals while crystallizing during welding. Weld Prod 9(4):1-8 
25. Borland JC (1960) Generalized theory of super-solidus cracking in welds (and castings). Br Weld J 7:508-512

26. Lippold JC (2015) Welding metallurgy and weldability. Welding metallurgy and weldability: $1-400$

27. Cross CE (2005) On the origin of weld solidification cracking. Hot Cracking Phenomena in Welds:3-18. https://doi.org/10.1007/3540-27460-X 1

28. Takalo T, Suutala N, Moisio T (1979) Austenitic solidification mode in austenitic stainless steel welds. Metall Trans A 10(8): 1173-1181. https://doi.org/10.1007/BF02811663

29. Kujanpaa VP, David SA, White CL (1986) Formation of hot cracks in austenitic stainless-steel welds - solidification cracking. Weld $\mathrm{J}$ 65(8):S203-S212

30. Lippold J, Savage W (1982) Solidification of austenitic stainless steel weldments: part III-the effect of solidification behavior on hot cracking susceptibility. Weld J 61(12):388

31. Wolf M (2006) Zur Phänomenologie der Heißrissbildung beim Schweißen und Entwicklung aussagekräftiger Prüfverfahren. Wirtschaftsverl. NW, Verlag für Neue Wiss.,

32. Wilken K, Kleistner H (1982) The MVT-test-a novel procedure for testing of the hot cracking susceptibility during welding. Mater Tech 1:3-10

33. Savage WF, Lundin CD (1965) The Varestraint test. Weld J 44(10): 433-442

34. Lundin CD, Lingenfelter A, Grotke G, Lessmann G, Mathews S (1982) The Varestraint test. Weld Res Counc Bull 280:19

35. Kannengiesser T, Boellinghaus T (2014) Hot cracking tests-an overview of present technologies and applications. Weld World 58(3):397-421. https://doi.org/10.1007/s40194-014-0126-y

36. Andersson J, Jacobsson J, Lundin C (2016) A historical perspective on Varestraint testing and the importance of testing parameters. In: Boellinghaus T, Lippold JC, Cross CE (eds) Cracking phenomena in welds IV. Springer International Publishing, Cham, pp 3-23. https://doi.org/10.1007/978-3-319-28434-7 1

37. Homberg G, Schmidtmann E (1979) Einfluss der Schweissparameter und der Zusammensetzung von Schweisszusatzwerkstoffen auf die Heissrissneigung im Schweissgut austenitischer Stähle

38. Goodwin G (1988) The effects of heat input and weld process on hot cracking in stainless steel. Weld J 67:88s-94s

39. Gollnow C (2015) Beitrag zur Ermittlung vorrangig konstruktiver Einflussgrößen auf die Heißrissinitiierung an geschweißten Bauteilen. Bundesanstalt für Materialforschung und-prüfung (BAM),

40. Coniglio N, Cross C (2016) Towards establishment of weldability testing standards for solidification cracking. In: Cracking phenomena in welds IV. Springer, Berlin, pp 37-66

41. ISO C (2004) TR 17641-3: destructive tests on welds in metallic materials. Hot cracking tests for weldments Arc welding processes Part 3

42. B4.0:2016 AA (2016) Standard method for mechanical testing of welds. American Welding Society, Miami

43. Zhu S, Yan B (2019) Effects of cerium on weld solidification crack sensitivity of 441 ferritic stainless steel. Metals 9(3):372

44. Statharas D, Atkinson H, Thornton R, Marsden J, Dong H, Wen S (2019) Getting the strain under control: Trans-Varestraint tests for hot cracking susceptibility. Metall Mater Trans A 50(4):1748-1762
45. Singh S, Hurtig K, Andersson J (2018) Investigation on effect of welding parameters on solidification cracking of austenitic stainless steel 314. Procedia Manuf 25:351-357

46. Abe D, Matsuzaka F, Murakami Y, Matsuoka T, Yamaoka H (2018) Determining the BTR by conducting a Trans-Varestraint test using a high-speed camera and two-color pyrometry. Weld World 62(6): 1237-1246

47. Singh S, Andersson J (2018) Hot cracking in cast alloy 718. Sci Technol Weld Join 23(7):568-574

48. Srinivasan G, Divya M, Das C, Albert S, Bhaduri A, Lauf S, Stubenrauch S, Klenk A (2015) Weldability studies on borated stainless steel using Varestraint and Gleeble tests. Weld World 59(1):119-126

49. Yushchenko K, Savchenko V, Chervyakov N, Zvyagintseva A, Guyot E (2011) Comparative hot cracking evaluation of welded joints of alloy 690 using filler metals InconelSr 52 and 52 Mss. Weld World 55(9-10):28-35

50. Arata Y, Matsuda F, Saruwatari S (1974) Varestraint test for solidification crack susceptibility in weld metal of austenitic stainless steels

51. Senda T, Matsuda F, Takano G, Watanabe K, Kobayashi T, Matsuzaka T (1971) Fundamental investigations on solidification crack susceptibility for weld metals with Trans-Varestraint test. Trans Jpn Weld Soc 2(2):141-162

52. Lippold JC, Sowards JW, Murray GM, Alexandrov BT, Ramirez AJ (2008) Weld solidification cracking in solid-solution strengthened Ni-base filler metals. Hot cracking phenomena in welds II: 147-170. https://doi.org/10.1007/978-3-540-78628-3 9

53. Karlsson L, Bergquist EL, Rigdal S, Thalberg N (2008) Evaluating hot cracking susceptibility of Ni-base SAW consumables for welding of $9 \%$ Ni steel. Hot cracking phenomena in welds ii:329 347. https://doi.org/10.1007/978-3-540-78628-3 17

54. Bradley D, Roth G (2007) Adaptive thresholding using the integral image. J Graph Tools 12(2):13-21

55. Beucher S (1979) Use of watersheds in contour detection. In: Proceedings of the international workshop on image processing. CCETT, Rennes

56. Hull F (1973) Delta ferrite and martensite formation in stainless steels. Weld J 52(5):193

57. Hammar ÖS, U. (1979) Solidification and casting of metals. Metals Soc 1979:401-410

58. Díez FM (2004) Development of compressive residual stress in structural steel weld toes by means of weld metal phase transformations. Colorado School of Mines, Golden

59. Kujanpaa V, Suutala N, Takalo T, Moisio T (1979) Correlation between solidification cracking and microstructure in austenitic and austenitic-ferritic stainless steel welds. Weld Res Int 9(2):55-75

60. Coniglio N, Cross CE (2008) Weld parameter and minor element effects on solidification crack initiation in aluminium. Hot cracking phenomena in welds II:277-310. https://doi.org/10.1007/978-3$540-78628-3 \quad 15$

Publisher's note Springer Nature remains neutral with regard to jurisdictional claims in published maps and institutional affiliations. 